\title{
Middle East Respiratory Syndrome: MERS
}

\author{
Emine Parlak \\ Atatürk University, Faculty of Medicine, Department of Infectious Diseases and Clinical Microbiology, Erzurum, Turkey
}

\begin{abstract}
Middle East respiratory syndrome coronavirus (MERS-CoV) is a newly emerging respiratory virus. It was first identified in Saudi Arabia in 2012. MERS-CoV infection is characterized by a spectrum of illness ranging from mild to acute and fulminant disease. The majority of patients present with fever, fever with chills/rigors, cough, shortness of breath, and dry cough. Cases of human-to-human transmission have been documented. There is currently no specific treatment and vaccination for MERS-CoV infection. Surveillance and infection-control measures are of vital importance to an efficient public health response. J Microbiol Infect Dis 2015;5(2): 93-98
\end{abstract}

Key words: Coronavirus, Middle East Respiratory Syndrome, MERS-CoV polymerase-chain-reaction, respiratory symptoms

\section{Orta Doğu Solunum Sendromu: MERS}

\section{ÖZET}

Orta Doğu Solunum Sendromu coronovirüsü (MERS-CoV) yeni ortaya çıan bir solunum virüsüdür. Bu virus ilk olarak 2012 yılında Suudi Arabistan'da tanımlanmıştır. Orta Doğu solunum sendromu koronavirüs enfeksiyonu akut hafif bir hastalık ile fulminan hastalık arasında değişen bir klinik spektrum ile karakterizedir. Hastaların çoğunluğunda ateş, ateş ile titreme, öksürük, nefes darlı̆ı̆ ve kuru öksürük bildirilmiştir. İnsandan insana bulaşan vakalar belgelenmiştir. MERS$\mathrm{CoV}$ enfeksiyonu için günümüzde özel bir tedavi ve aşılama yoktur. Sürveyans ve infeksiyon kontrol önlemleri halk sağıı̆ı için hayati öneme sahiptir.

Anahtar kelimeler: Coronavirüs, Ortadoğu solunum sendromu, MERS-CoV, polimeraz zincir reaksiyonu, solunum semptomları

\section{INTRODUCTION}

Coronaviruses (CoVs) have envelopes and positive RNA and are generally responsible for the common cold. More rarely, they may cause severe respiratory tract diseases. The first human CoV was isolated in 1960. Six human CoVs have been identified to date; HCoV-229E, HCoV-OC43, HCoV-NL63, HKU1-CoV, MERS-CoV and SARS-CoV. The latter two lead to severe infections. ${ }^{1}$

Severe acute respiratory syndrome (SARS) is a viral disease responsible for numerous deaths in 2003. The first case was reported from China in 2002. A total of 8273 probable cases of SARS were reported worldwide in 2002-2003, with 775 deaths. ${ }^{2}$ The virus has been shown to spread easily and continually from human to human via droplets. The incubation period is 2-10 days (mean 4 days).
Fever, muscular pain, headache, shivering and diarrhea are common in these cases. Respiratory difficulty and dry cough generally follow within 5-7 days. Twenty to thirty percent of cases have been monitored in intensive care units. The acute respiratory distress syndrome (ARDS)-related death rate is $\sim 10-15 \% .^{3}$

CoVs consist of alpha, beta, gamma, and delta groups. MERS and SARS belong to the beta group of this broad family. ${ }^{1}$ Although they are very similar to one another, the fact that they are remotely connected is troubling. According to some data, similar findings have recently been reported between MERS and SARS. ${ }^{4}$ Advanced epidemiological examination, however, has confirmed that MERS and SARS are different entities. Epidemic curves show that MERS exhibits a sporadic pattern and SARS an epidemic pattern. ${ }^{2}$ 
The MERS-CoV genome is 30119 nucleotides in length. ${ }^{5} \mathrm{~A}$ new CoV that leads to contagious respiratory disease is MERS-CoV. This was first described in a male Saudi patient with severe pulmonary infection in June $2012 .{ }^{6}$ The majority of cases have been seen in Saudi Arabia and Middle Eastern countries or in subjects in close contact with visitors to these. Since Middle Eastern countries predominate, the condition is known as "Middle East Respiratory Syndrome Coronavirus". MERS-CoV is the name recognized by the World Health Organization (WHO), the Saudi Ministry of Health, the discoverers of the virus and other researchers. The disease it causes is known as MERS for short. 7,8

\section{Countries in Which Cases of MERS Have Been Reported}

The virus is most commonly distributed in Middle Eastern countries. The disease has been reported as a cause of respiratory disease in patients from Saudi Arabia, Qatar, Jordan, the United Kingdom, Germany, France, Tunisia, the United Arab Emirates, Oman, Kuwait, Egypt, Italy, Tunisia, Greece, Yemen, Lebanon, Iran, Algeria, Malaysia, the USA, the Netherlands, the Philippines and Turkey. The virus exhibits a broad geographic distribution, from Tunisia and Egypt in Africa and Asian countries such as Malaysia and the Philippines to the USA. 2,4,7,8

The WHO does not recommend restrictions on trade or travel and screening on entry for these countries. All European and North African cases to date have been directly or indirectly linked to the Middle East. Some cases in Tunisia, Great Britain, Italy and France have had no history of Middle Eastern travel, although a history of contact with individuals who travel to the Middle East has been established. ${ }^{4,9}$ Limited contagion has been observed between close contacts. ${ }^{10}$ Clustering in epidemics has occurred in the same family, hospital or work place. ${ }^{11}$

\section{First Clusters}

The first cluster was reported in a family from Saudi Arabia. MERS CoV was confirmed in three out of four cases of respiratory disease aged 16-70. Diarrhea, abdominal pain and anorexia accompanied the infection. Two of the patients died. ${ }^{11}$

MERS-CoV transmission was shown from a patient hospitalized after traveling to Dubai to a patient living in France with no history of travel but sharing the same room as the patient. Genetic analysis confirmed nosocomial transmission from the first patient. ${ }^{9}$

Thirty-three 135 contacts were reported in a British epidemic, person-to-person transmission was documented this epidemic. No disease was detected in 59 health workers, while two patients were positive. An attack rate of $6 \%$ was determined. ${ }^{12}$

Transmission occurred from the same work place in an Italian epidemic; 144 contacts were observed. Respiratory specimens were investigated from the majority of these. Seventy proved negative and three positive. Very close contact was identified. For example, clustered cases in Italy all worked in the same place. ${ }^{13}$

\section{Virus Transmission}

As proved in the British epidemic, transmission may occur through close contact from one person to another. ${ }^{12}$ The virus is thought to be transmitted via the respiratory tract (droplets). Interpersonal transmission is not as fast as that of SARS. Such transmission has been demonstrated in the absence of compliance with infection control procedures. Apart from small clusters (family members, patients in hospital and health workers), continual transmission from one person to another has not been observed. ${ }^{5,9,10,12,14}$ Human to human transmission of MERS-CoV has been reported in several clusters of cases in different countries including among family members and health care workers. ${ }^{13-17}$ For MERS$\mathrm{CoV}$, asymptomatic infections have recently been identified in children and health workers. However, whether these individuals can efficiently transmit infection is still unclear. ${ }^{18}$

Research has shown that to date MERS-CoV has no pandemic potential. ${ }^{10}$ However, more sporadic cases through limited transmission are expected to occur..$^{19}$ It is important for the number of personnel entering a room containing an infected patient to be kept as low as possible. Contact must also be reduced to a minimum. Patient rooms should be equipped with HEPA filters if possible. The patient must not be allowed out of the room..$^{8,20}$

\section{Clinical Features in Cases of MERS}

The most common symptoms are fever (98\%), chills I fever with chills $(87 \%)$, cough $(83 \%)$, respiratory difficulty $(72 \%)$ and dry cough (56\%). ${ }^{7}$ Headache, sore throat, runny nose, nausea, dizziness, phlegm, diarrhea, abdominal pain and other gastrointestinal symptoms are also seen. Other signs and findings are shortness of breath, myalgia, pericarditis and coagulopathies. ${ }^{7,8}$ 
The largest clinical case series published to date involved 47 patients; most had fever (98\%), cough (83\%), and shortness of breath (72\%). Many also had gastrointestinal symptoms (diarrhea in $26 \%$ and vomiting in $21 \%$ ). ${ }^{21}$

A gastrointestinal symptom, such as diarrhea, has sometimes been the initial finding. The disease must be considered when sudden onset respiratory tract infection is determined together with fever and cough. ${ }^{9}$ Severe respiratory tract disease requiring hospitalization (ARDS) and kidney failure requiring dialysis may develop. ${ }^{22,23}$ The course may be mild or asymptomatic in some patients. The clinical course may vary in immune-suppressed individuals. The kidney has been reported as the primary virus replication site and urine as a source of transmission in humans. ${ }^{23}$

Cases are range in age from 14 months to 94 years (median age 50 ). The majority $(65 \%)$ are male. The male to female ratio in studies is 2.63.3:1. The virus predominantly leads to infection in middle age or later. ${ }^{24} \mathrm{~A}$ mild clinical course has been observed in child patients. The incubation period for secondary cases is $2-13$ days (median 5 days). ${ }^{12} \mathrm{~A}$ time frame of 9-12 days was reported in one study. ${ }^{10}$ Mean duration from onset of disease to presentation at hospital is 4 days, and median time to admission to intensive care is 5 days. Monitoring on a mechanical ventilator in the intensive care unit is recommended in severe cases entering respiratory failure. Bacterial and fungal co-infections have been reported in patients attached to mechanical ventilators. Duration of spread of MERS-CoV from pulmonary and non-pulmonary sources is unclear. Lower respiratory tract infections exhibit a higher viral load and longer duration than upper respiratory tract infections. The virus has also been isolated from feces, serum and urine. Mean time between onset of disease and death is approximately 12 days. . $^{84,25}$

Individuals with underlying medical conditions are thought to be more susceptible to infection. Comorbidities (chronic cardiac disease, chronic kidney disease and diabetes mellitus) are present in most cases. The virus causes more severe disease in the elderly and individuals with weakened immune systems and chronic diseases, such as chronic lung disease, diabetes and cancer. ${ }^{14,21,23}$ The majority of patients $(96 \%)$ reported have had one or more chronic medical conditions, including diabetes $(68 \%)$, hypertension $(34 \%)$, heart disease $(28 \%)$, and kidney disease (49\%). Thirty-four $(72 \%)$ had more than one chronic condition. ${ }^{21}$ Septic shock, multiorgan failure and death have been reported in severe cases. ${ }^{9,11}$

\section{Radiological Findings}

Unilateral (43\%) or bilateral (22\%) patch type areas of density, increased bronchovascular narrowing $(17 \%)$, opacities, interstitial infiltrations, widespread reticulonodular pattern $(4 \%)$, consolidation and pleural effusion have been seen at $\mathrm{x}$-ray. ${ }^{7}$

Acute respiratory failure, ARDS and refractory hypoxemia have been reported to accompany the infection. Non-pulmonary complications such as acute kidney injury requiring renal replacement, hypotension requiring vasopressor, hepatic infection and septic shock have been reported in some patients..$^{8,24,25}$

\section{Laboratory Findings}

Leukopenia, lymphopenia, thrombocytopenia and elevated lactase dehydrogenase are generally present on admission. 9 In the first case of MERS, white blood cell count was normal on admission (albeit $92.5 \%$ neutrophil), while leukocytosis, neutrophilia, lymphopenia and progressive thrombocytopenia were reported on the 10th day. ${ }^{6}$ In another study, laboratory analyses showed raised concentrations of lactate dehydrogenase (49\%), aspartate aminotransferase $(15 \%)$, thrombocytopenia $(36 \%)$ and lymphopenia $(34 \%){ }^{21}$

\section{Diagnosis of Probable MERS-COV}

Infection should be suspected in individuals with acute severe respiratory failure and/or pulmonary infiltration, as well as in subjects who have traveled to countries where cases have been reported within the previous 14 days. Individuals who have come into close contact within the previous 14 days with a person with a history of travel to countries where cases are reported and who develop symptoms within 14 days of such contact are also at risk. ${ }^{25}$

\section{Diagnosis of Definite MERS-COV}

Diagnosis is made on the basis of laboratory confirmation of MERS-CoV infection, irrespective of clinical signs and symptoms. ${ }^{25}$

Two million people from 180 countries, including 1 million pilgrims, visit Mecca and Medina in every year. Surveillance must be performed quickly, accurately and continuously in order to determine the true spread. Widespread use of serological tests and surveillance are important if appropriate precautions are to be taken. ${ }^{12,22}$ 


\section{Source}

Patterns of transmission of MERS CoV remain unclear. The disease is thought to be zoonotic. It bears a close genetic similarity to bat coronaviruses. A similar gene segment was identified in a single bat. ${ }^{4}$ Human strains have been isolated from camels in Egypt, Qatar and Saudi Arabia. ${ }^{26}$ MERS-CoV antibodies have been found in camels in Africa and the Middle East. Camels are thought to be a source of human infection..$^{8,25-27}$ Genetic sequence similarities have been determined between human and camel viruses. ${ }^{14,26}$ Transmission from dromedary camels to humans has been shown with RT-PCR. Viral genome sequence analysis, molecular detection and phylogenetic analysis have been performed in order to investigate transmission. ${ }^{28}$ Other animals, such as goats, cows, sheep, buffalo, pigs and wild birds have been tested for MERS-CoV antibodies, but no positive findings have been reported. ${ }^{27}$

General hygiene procedures are essential, including hand washing before and after animal contact. The consumption of animal products such as milk and meat that are not properly prepared or cooked also carries a risk of infection. Camel meat and milk can be consumed if cooked or pasteurized. Since the disease can exhibit a severe course in individuals with diabetes, kidney failure, chronic lung disease or immune suppression, these patients are advised to avoid unprocessed camel milk, urine and raw meat. ${ }^{8,25}$

\section{Diagnosis}

Lower respiratory tract specimens (tracheal aspirate, bronchiolar lavage and pleural fluid) are preferred in sample collection. ${ }^{7,9}$ In the event that lower respiratory tract specimens cannot be taken, upper respiratory tract specimens such as nose-throat and nasopharyngeal smears can be used. The WHO strongly recommends lower respiratory tract samples, however. ${ }^{8}$ Samples 2-3 $\mathrm{ml}$ in size must be placed in non-leak screw top sterile bowls. These must be immediately sent to the laboratory under viral specimen transport conditions (virocult or similar). They can be stored in a refrigerator (at 2-8 decrees) for 72 hours. If transportation exceeds 72 hours, specimens must be kept at -70 and packed in dry ice. A case information form must be completed with the specimen. The fully completed form must be placed inside a protective envelope and attached to the outer surface of the transport box containing the specimens. Brief details of the procedure required (coronavirus) should also be attached to the box. Transfer of specimens must be performed under cold chain and biosecure conditions. It is important for specimens to be collected within 3 days of onset of symptoms. ${ }^{8,25}$

Reverse transcriptase polymerase chain reaction (RT-PCR) is used for diagnosis., ${ }^{7,24}$ Diagnosis can be confirmed using reverse transcription RTPCR on bronchoalveolar lavage, sputum and tracheal aspirates. ${ }^{29,30}$ The «upstream $\mathrm{E}$ protein, upE gene» and "ORF1a» genes are targeted for definitive diagnosis. In the event that both tests are positive, infection is regarded as present. ${ }^{9}$ Some authors have recommended using upE for screening and ORF1b for confirmation. The test should be repeated in suspected cases with negative RT-PCR results. The literature advises the screening of patients and family members with a potential history of exposure to MERS-CoV. ${ }^{30}$

\section{Healthcare Workers and the Risk of MERS-COV}

Severe respiratory disease was reported among 10 healthcare workers in the Jordanian epidemic 31. Moderate respiratory symptoms were observed in 13 healthcare workers in Great Britain, of whom 10 were seronegative. ${ }^{24}$ One hundred twenty-four healthcare workers and 24 relatives remained healthy in another family outbreak. ${ }^{11}$

Infection control procedures are important in order to prevent possible spread of MERS-CoV in health institutions. ${ }^{24}$ Hospitals must take appropriate measures to prevent transmission to other patients, healthcare workers and visitors. ${ }^{32}$ The disease has been detected in healthcare workers in several countries. Droplet precautions must be added to standard procedures in caring for patients with symptoms of acute respiratory tract infection. Contact procedures and eye protection must be added to other measures in cases in which MERS$\mathrm{CoV}$ infection is confirmed or contact is suspected. Airway protection measures must be applied during aerosol producing procedures. . $^{8,25}$

Health institutions caring for patients with confirmed or suspected MERS-CoV infection must take measures to reduce the risk of transmission of the virus to a minimum. Healthcare workers must be properly trained and possess infection prevention and control skills. ${ }^{8}$

\section{Treatment}

There is currently no specific treatment and vaccination for MERS-CoV infection. ${ }^{32,33}$ Treatment is based on support therapies including infection control procedures and management of complications. Although levels of evidence vary, convales- 
cent plasma, ribavirin, interferon, protease inhibitors, intravenous immunoglobulin, corticosteroids and cyclosporine are all under investigation. ${ }^{7,32,34}$ Recent studies have emphasized the potential role of ribavirin and interferon. ${ }^{7}$ One paper published in the Lancet recommended pegylated interferon (1.5 $\mathrm{mcg} / \mathrm{kg}$ every week) together with ribavirin at a loading dose of $2000 \mathrm{mg}$ followed by $1200 \mathrm{mg}$ (at 8-hour intervals for 4 days), and then $600 \mathrm{mg}$ (at 8-hour intervals for 4-6 days). ${ }^{27}$ Severe MERS-CoV is associated with poor overall survival. Treatment with oral ribavirin and subcutaneous pegylated interferon alfa-2a is associated with significantly improved survival at 14 days, but not at 28 days. ${ }^{35}$ Compared with the SARS virus, MERS-CoV infection is $50-100$ times more sensitive to interferon in an in vitro environment. ${ }^{33}$

\section{Mortality}

A mortality rate of $50-60 \%$ was reported in the earliest publications. ${ }^{4,10}$ Assiri et al.'s 27 study reported particularly high mortality $(60 \%)$. The rate has subsequently fallen with the addition of asymptomatic and mild cases in recent papers. ${ }^{14}$ The current mortality level among confirmed cases is approximately $28-30 \% .^{8,26}$

\section{Protection}

Care must be taken over hand and environmental hygiene. Medical masks, gloves, and aprons must be worn when approaching patients with suspected or confirmed MERS infection. The following pre- cautions must be taken in caring for patients with suspected or confirmed MERS-CoV infection: the number of health personnel and visitors entering the room must be limited. Such visitors must be informed of infection control procedures. Individuals entering the room or approaching less than 1 meter from the patient must wear surgical masks, protective goggles and long-sleeved surgical gowns. Care must be taken with hand hygiene, patient equipment must be kept separate and, if possible, used only once. If the same equipment has to be used between patients, it must be disinfected first. Patients must be isolated in adequately ventilated rooms, and each patient must be placed in a separate room. If that is not possible, patients with the same diagnosis may be placed in one room. If that is also not possible, a distance of at least 1 meter must be maintained between beds, and isolation must be ensured with screens or curtains. The patient must not be removed from the isolation room except in case of medical necessity. When removal from the isolation room is required for medical reasons, the patient must wear a surgical mask, and transportation must be performed such as to reduce contact with other people to a minimum. The destination unit must be informed beforehand, and the requisite preparations must be made there before arrival. Surfaces coming into contact with the patient, such as beds and chairs, must be cleaned with disinfectant. Scrupulous care must be taken over infection procedures..$^{8,15,36}$ (Table 1).

Table 1. MERS CoV preventive advice for travelers to the Middle East a 36

1. Wash your hands with soap and water or apply an alcohol solution.

2. Cover your mouth and nose with a tissue while coughing or sneezing.

3. Avoid hand shaking or touching your mouth, nose and eyes with your hands.

4. Avoid contact with patients with respiratory symptoms.

5. Avoid contact with domestic or wild animals (e.g. camels).

6. Avoid contact with animal secretions (e.g. urine, faeces).

7. Avoid consumption of unpasteurized milk (in particular from camels), or meat inadequately cooked.

8. Avoid consumption of fruit and vegetables which are not washed or peeled by yourself.

9. If you develop any respiratory symptoms during your trip seek medical attention immediately, report your recent trip and postpone your return until you have fully recovered.

10. After returning from countries of the Middle East, if within 14 days you develop fever $38^{\circ} \mathrm{C}$ or more and respiratory symptoms (cough, shortness of breath, etc) you should seek medical attention immediately and inform your doctor about your recent trip.

11. If you are a pilgrim traveling for Hajj and Umrah and above 65 years of age, or if you suffer from chronic diseases (e.g. heart, kidney or respiratory disease, diabetes, congenital or acquired immune deficiency, malignancy or terminal illness, or if you are a pregnant women or a child ( $<12$ years of age), you may consider postponing the performance of the Hajj and Umrah for your own safety b

a In accordance with WHO, CDC,

b The Saudi Ministry of Health $(\mathrm{MoH})$ recommendations 


\section{CONCLUSION}

MERS is a viral respiratory disease involving a new coronavirus. All cases to date have been directly or indirectly linked to the Middle East. Limited epidemiological data suggest that it is primarily a zoonotic disease. Most cases involve males. The disease can also be transmitted from person to person, albeit in a limited manner. It has also been shown to be transmitted nosocomially. Fever, cough and respiratory difficulty are observed in typical MERS disease. The disease may also be manifest with mild symptoms or else be asymptomatic. Respiratory tract disease has been part of the disease in most cases. Severe acute respiratory tract disease requiring hospitalization has been observed in severe cases. Lower respiratory tract specimens must be collected from probable cases. Standard, contact and airway precautions must be applied in MERSCoV patients. Scrupulous compliance with infection control procedures in hospitals is essential. Patients meeting clinical criteria should be closely questioned about travel and contacts.

\section{REFERENCES}

1. De Groot RJ, Baker SC, Baric RS, et al. Middle East respiratory syndrome coronavirus (MERS-CoV): Announcement of the coronavirus study group. J Virol 2013;87:7790-7792.

2. Maclntyre CR. The discrepant epidemiology of Middle East respiratory syndrome coronavirus (MERS-CoV). Environ Syst Decis 2014;34:383-390.

3. Bermingham A, Chand MA, Brown CS, et al. Severe respiratory illness caused by a novel coronavirus, in a patient transferred to the United Kingdom from the Middle East, September 2012. Euro Surveill. 2012;17:20290.

4. Announcement of the Coronavirus Study Group. Middle East Respiratory Syn 1 drome Coronavirus (MERS-CoV). J. Virol 2013;87:77907792.

5. Raj VS, Osterhaus AD, Fouchier RM, et al. MERS: emergence of a novel human coronavirus. Curr Opin Virol 2014;5:58-62.

6. Zaki AM, van Boheemen S, Bestebroer TM, et al. Isolation of a novel coronavirus from a man with pneumonia in Saudi Arabia. N Engl J Med 2012;367:1814-1820.

7. Al-Tawfiq JA, Assiri A, Memish ZA. Middle East respiratory syndrome novel corona (MERS-CoV) infection Epidemiology and outcome update. Saudi Med J 2013;34:991-994.

8. World Health Organization. Global alert and response (GAR): pandemic and epidemic diseases (http://www.who.int/csr/disease/en/)

9. Guery B, Poissy J, el Mansouf L, et al. Clinical features and viral diagnosis of two cases of infection with Middle East Respiratory Syndrome coronavirus: A report of nosocomial transmission. Lancet 2013;381:2265-2272.

10. Breban R, Riou J, Fontanet A. Interhuman transmissibility of Middle East respiratory syndrome coronavirus: estimation of pandemic risk. Lancet 2013;382:694-699.

11. Memish ZA, Zumla Al, Al-Hakeem RF, et al. Family cluster of Middle East respiratory syndrome coronavirus infections. N Engl J Med 2013;368:2487-2494

12. Health Protection Agency (HPA) UK Novel Coronavirus Investigation Team. Evidence of person-to-person transmission within a family cluster of novel coronavirus infections, United Kingdom, February 2013. Euro Surveill 2013;18:20427.
13. Puzelli S, Azzi A, Santini MG, et al. Investigation of an imported case of Middle East Respiratory Syndrome Coronavirus (MERS-CoV) infection in Florence, Italy, May to June 2013. Euro Surveill 2013;18:20564.

14. Abroug F, Slim A, Ouanes-Besbes L. Family cluster of Middle East respiratory syndrome coronavirus infections, Tunisia, 2013 Emerg Infect Dis 2014;20:1527-1530.

15. Assiri A, McGeer A, Perl TM, et al. Hospital outbreak of Middle East respiratory syndrome coronavirus. N Engl J Med 2013;369:407-416.

16. Cotten M, Watson SJ, Kellam P, et al. Transmission and evolution of the Middle East respiratory syndrome coronavirus in Saudi Arabia: a descriptive genomic study. Lancet 2013;382:1993-2002.

17. Omrani AS, Matin MA, Haddad Q, et al. A family cluster of Middle East respiratory syndrome coronavirus infections related to a likely unrecognized asymptomatic or mild case. Int J Infect Dis 2013;17:e668e672.

18. De Sousa R, Reusken C, Koopmans M. MERS coronavirus: Data gaps for laboratory preparedness. J Clin Virol 2014;59:4-11.

19. Bauch CT, Oraby T. Assessing the pandemic potential of MERS-CoV. Lancet 2013;382:662-664.

20. Drosten C, Seilmaier M, Corman VM, et al. Transmission of MERSCoronavirus in household contacts. N Engl J Med 2014;371:828-835.

21. Assiri A, Al-Tawfiq JA, Al-Rabeeah AA, et al. Epidemiological, demographic, and clinical characteristics of 47 cases of Middle East respiratory syndrome coronavirus disease from Saudi Arabia: a descriptive study. Lancet Infect Dis 2013;13:752-761.

22. Memish ZA, Almasri M, Turkestani A, et al. Etiology of severe community-acquired pneumonia during the 2013 Hajj-part of the MERS-CoV surveillance program. Int J Infec Dis 2014;25:186-190.

23. Eckerle I, Müller MA, Kallies S, et al. In-vitro renal epithelial cell infection reveals a viral kidney tropism as a potential mechanism for acute renal failure during Middle East Respiratory Syndrome (MERS) Coronavirus infection. Virol J 2013;10:359.

24. Memish ZA, Al-Tawfig JA, Makhdoom HQ, et al. Screening for Middle East respiratory syndrome coronavirus infection in hospital patients and their healthcare worker and family contacts: a prospective descriptive study. Clin Microbiol Infect 2014;20(5):469-474.

25. http://who.int/csr/disease/coronavirus_infections/MERS_home

26. Memish MA, Cotton M, Meyer B, et al. Human Infection with MERS Coronavirus after Exposure to Infected Camels, Saudi Arabia, 2013. Emerg Infect Dis 2014;20:1012-1015.

27. Reusken $\mathrm{CB}$, Lina $\mathrm{PH}$, Pielaat $\mathrm{A}$, et al. Middle East respiratory syndrome coronavirus neutralising serum antibodies in dromedary camels: a comparative serological study. Lancet Infect Dis 2013;13:859866.

28. Azhar El, El-Kafrawy S A, Farraj S A, et al. Evidence for Camelto-Human Transmission of MERS Coronavirus. $\mathrm{N}$ Engl J Med 2014;370:2499-2505.

29. Cotten M, Watson SJ, Kellam P, et al. Transmission and evolution of the Middle East respiratory syndrome coronavirus in Saudi Arabia: a descriptive genomic study. Lancet 2013;382:1993-2002.

30. Corman V, Eckerle I, Bleicker T, et al. Detection of a novel human coronavirus by real-time reverse-transcription polymerase chain reaction. Euro Surveill 2012;17:20285.

31. Hijawi B, Abdallat M, Sayaydeh A, et al. Novel coronavirus infections in Jordan, April 2012: epidemiological findings from a retrospective investigation. East Mediterr Health J. 2013;19:S12-18.

32. Momattin H, Mohammed K, Zumla A, et al. Therapeutic Options for Middle East Respiratory Syndrome Coronavirus (MERS-CoV) - possible lessons from a systematic review of SARS-CoV therapy. Int J Infect Dis 2013;17:e792-e798.

33. Balkhair A, Al Maamari K, Alawi FB. The struggle against MERS-CoV (The Novel Coronavirus). Oman Med J 2013;28:226-227.

34. Wilde AH, Raj S, Oudshoorn D, et al. MERS-coronavirus replication induces severe in vitro cytopathology and is strongly inhibited by cyclosporin A or interferon-a treatment. J Gen Virol 2013;94:1749-1760.

35. Omrani AS, Saad MM, Baig K, et al. Ribavirin and interferon alfa-2a for severe Middle East respiratory syndrome coronavirus infection: a retrospective cohort study. Lancet Infect Dis 2014;14:1090-1095.

36. Pavli A, Tsiodras S, Maltezou HC. Middle East respiratory syndrome coronavirus (MERS-CoV): Prevention in travelers. Travel Med and Infect Dis 2014;12:602-608. 